\title{
The Uffington White Horse geoglyph as sun-horse
}

Joshua Pollard*

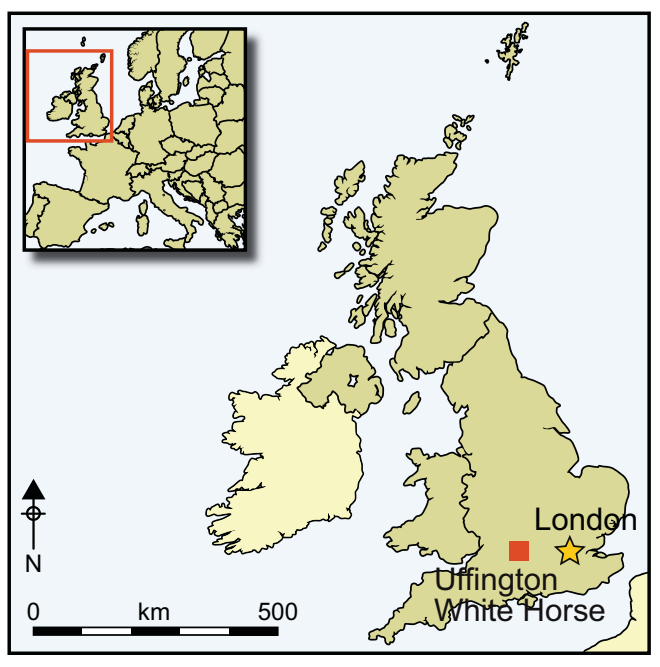

The Uffington White Horse is a unique later prehistoric geoglyph worked onto the chalk hillside of the Berkshire Downs in southern England. This large figure has seen little new interpretation since the early twentieth century. Unable to explain the form satisfactorily, archaeologists have shied away from acknowledging the distinct nature of the horse and its probable importance to previous occupants of the land. By reviewing the image's context within the broader archaeological landscape, the argument can now be made that the Uffington carving is a representation of the sun-horse found in iconography throughout later prehistoric Europe.

Keywords: England, later prehistory, Uffington White Horse, sun-horse, landscape

\section{Introduction}

The Uffington White Horse is Europe's only confirmed prehistoric hill-figure or geoglyph, and is among the oldest anywhere in the world. Created in the later second or first millennium $\mathrm{BC}$, it is also unusual in being a figurative representation within a surprisingly resilient tradition of non-representational imagery in prehistoric Britain (Figure 1). It is quite distinct from the only other form of prehistoric landscape art known in the British Isles: the abstract motifs that make up rock art panels within upland regions (Bradley 1997). A widely used image within popular culture, the White Horse features on album covers by XTC and Nirvana, and in fictional literature by Rosemary Sutcliffe, A.J. Hartley and Terry Pratchett. Its most famous literary incarnation comes in Thomas Hughes's (1859) The scouring of the White Horse, a semi-fictional account of the last great festival linked to the 'scouring' or cleaning of the horse held in 1857. While popular culture has found no difficulty in accommodating explanations of its meaning and role, the same cannot be said of archaeology. The most recent detailed evaluation of the geoglyph and its date

* Department of Archaeology, University of Southampton, Avenue Campus, Highfield, Southampton SO17 1 BF, UK (Email: c.j.pollard@soton.ac.uk) 


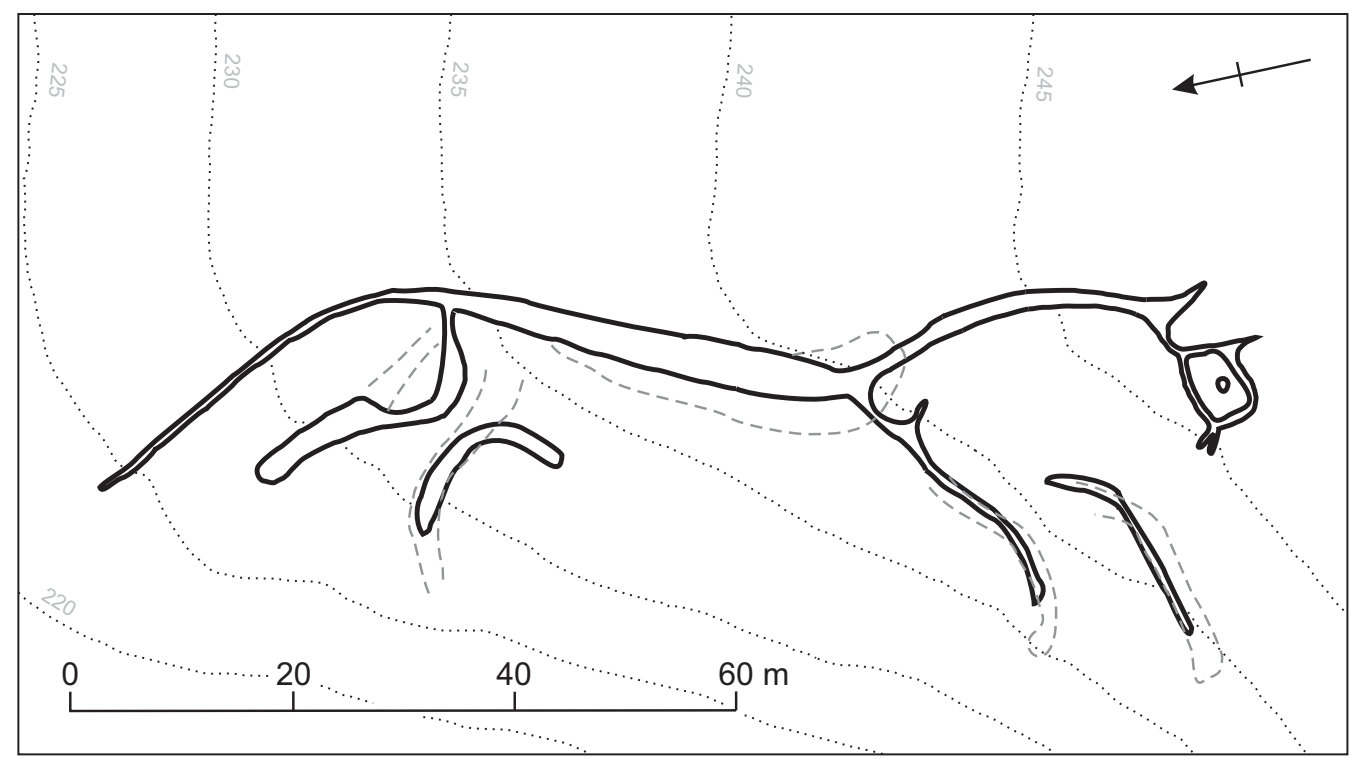

Figure 1. The Uffington geoglyph. Broken lines indicate geophysical anomalies (after Miles et al. 2003a).

concludes that "nobody can be certain now why the monument was originally constructed" (Barclay et al. 2003a: 245). It may be its apparent uniqueness that creates problems (cf. Jones 2012). Unlike the better-known palaeo-geoglyphs from the Americas-the Nazca Lines and the Late Woodland effigy mounds, for example-the Uffington figure lacks obvious comparanda and context, and so remains a rather awkward oddity. This explains its marginalisation in academic discourse.

By engaging with its landscape setting, and by locating the White Horse within current knowledge of European later prehistoric cosmologies, it is argued here that the figure served as a sun-horse image: a device connected with the diurnal passage of the sun through the sky. Further, taking an interpretive approach that recognises the multi-temporality of landscape (Gosden \& Lock 1998; Lucas 2005) — that is, the ongoing co-presence of earlier features within a landscape - offers a context for envisaging other modified and constructed features of the Uffington environs as appropriated components of a monument-complex centred on the horse.

\section{The Uffington geoglyph: its setting and its date}

The White Horse geoglyph is situated on the northern escarpment of the Berkshire Downs, in west Oxfordshire. The figure stretches over approximately $110 \mathrm{~m}$, its body following the upper edge of a steep re-entrant valley. Its form is elongated and abstract, with a curious beaked mouth and overlong tail. Geophysical survey and excavation in 1990 and 1994 by the then English Heritage and Oxford Archaeological Unit demonstrated that the morphology and the position of the horse have altered little since its creation, although its inclination relative to the hillslope has decreased by around $10^{\circ}$ (Miles et al. 2003a: 77), suggesting that it was formerly more visible from a close vantage point. The figure was 
originally formed through down-cutting and exposure of the white Upper Chalk bedrock. Subsequently, it was maintained through the successive addition of layers of puddled chalk (Miles et al. 2003a).

Other monuments lie within the immediate vicinity of the horse (Figure 2). Uffington hillfort lies 200m upslope to the south-south-west, while between this and the horse are a Bronze Age round barrow and a possible Neolithic long mound, reused in the late Roman period as an inhumation cemetery (Barclay et al. 2003b). Less than $200 \mathrm{~m}$ to the north, on the downslope of the escarpment, is the mound of Dragon Hill. The latter is probably a natural knoll that has been substantially modified and provided with a terraced summit. These monuments sit within a larger landscape rich in later prehistoric archaeology: within a radius of $5 \mathrm{~km}$ are the later Bronze Age-Iron Age hillforts of Rams Hill, Hardwell Camp and Alfred's Castle (Figure 3); extensive traces of field-systems, linear ditches and settlement areas; the earlier barrow cemetery at Lambourn Seven Barrows and the Neolithic chambered tomb of Wayland's Smithy (Bradley \& Ellison 1975; Whittle 1991; Bowden et al. 1993; Gosden \& Lock 2013).

The earliest documentary reference to the geoglyph dates to the late eleventh century AD (Marples 1949: 53-54). Full details of its documented history are given by Cromarty et al. (2003: 15-27). Direct evidence of its prehistoric origin is provided by optically stimulated luminescence (OSL) dates on colluvium samples pre-dating and interleaved between early episodes of redefinition of the horse. These provide a range of 1380-550 BC (68\% confidence) for the construction of the first horse (Rees-Jones \& Tite 2003), placing it within a horizon that extends from the middle Bronze Age to the latter part of the early Iron Age. That horizon represents an especially busy time for this landscape, taking in the highly elaborate inner enclosure at Rams Hill (Bradley \& Ellison 1975), dated to between the thirteenth and tenth centuries BC (Needham \& Ambers 1994), major linear ditches, the construction of the hillforts at Uffington and Alfred's Castle during the eighth to sixth centuries BC (Lock et al. 2003; Gosden \& Lock 2013) and the eighth-century BC open settlement at Tower Hill (Miles et al. 2003b).

\section{Reading the horse}

To date, the better chronology now available has not facilitated a new interpretation of the White Horse. In the most recent detailed assessment of the geoglyph, an established view of the horse as a symbol is retained, potentially "signalling the presence and wealth of the inhabitants of the ridge top, or [...] mark[ing] the presence of a site of special significance to the wider population" (Barclay et al. 2003a: 245). This goes little further than earlier interpretations of the horse as, variously, a landmark, a commemorative image, the "emblem or badge of some chiefdom or tribe", or as totemic, "embodying the identity of the white-horse people” (Marples 1949: 49; see also Crawford 1929; Piggott 1931). Without immediate analogy, and as an apparently unique and representational thing, conceiving of the horse as a sign for something - a place, a people, an event or social prowesshas an obvious economy. Suggestions that the geoglyph held religious significance, "as a kind of cult object" (Marples 1949: 50; see also Piggott 1931), have met with increasing unpopularity since the mid twentieth century.

(C) Antiquity Publications Ltd, 2017 


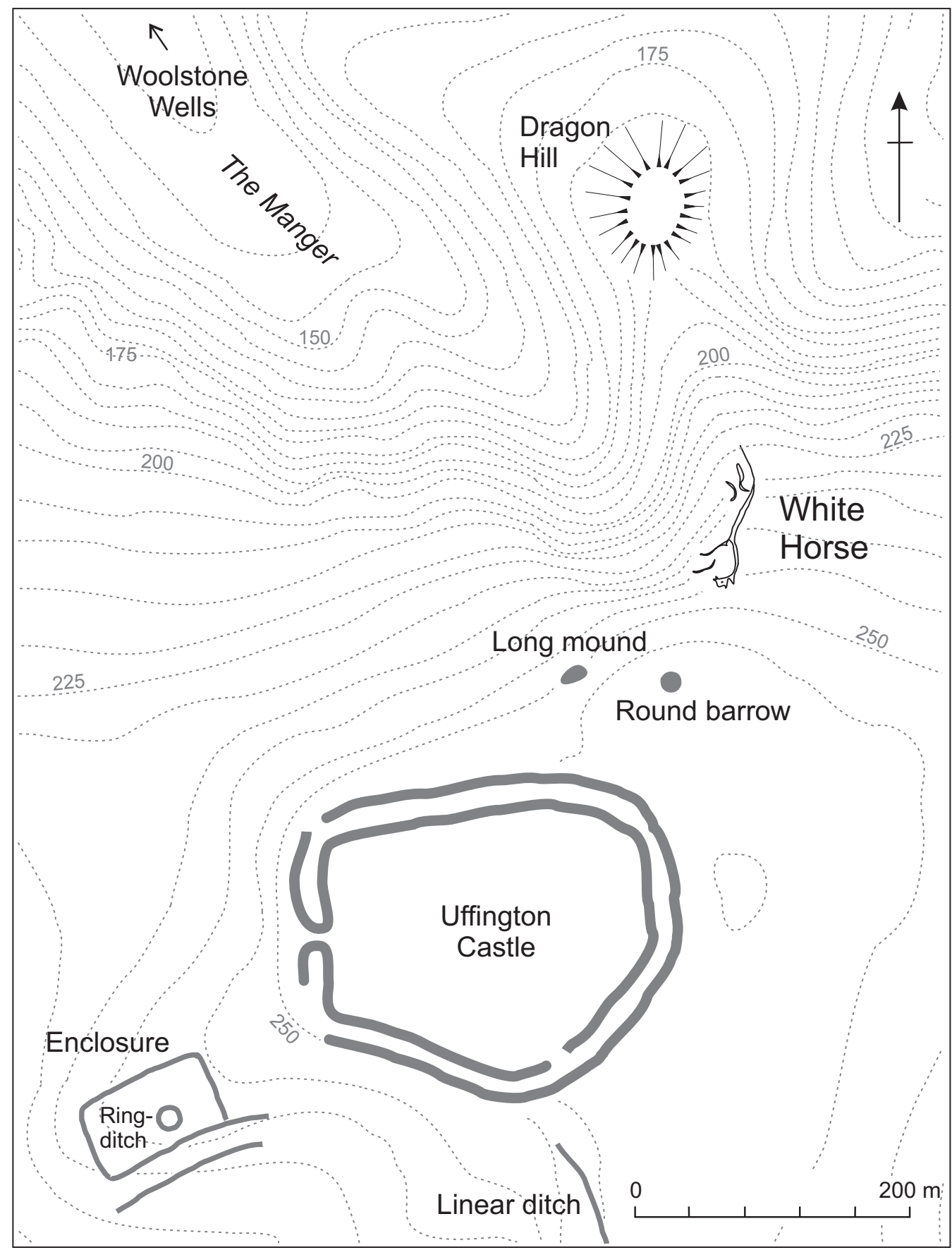

Figure 2. The White Horse and adjacent sites (after Barclay et al. 2003b). 


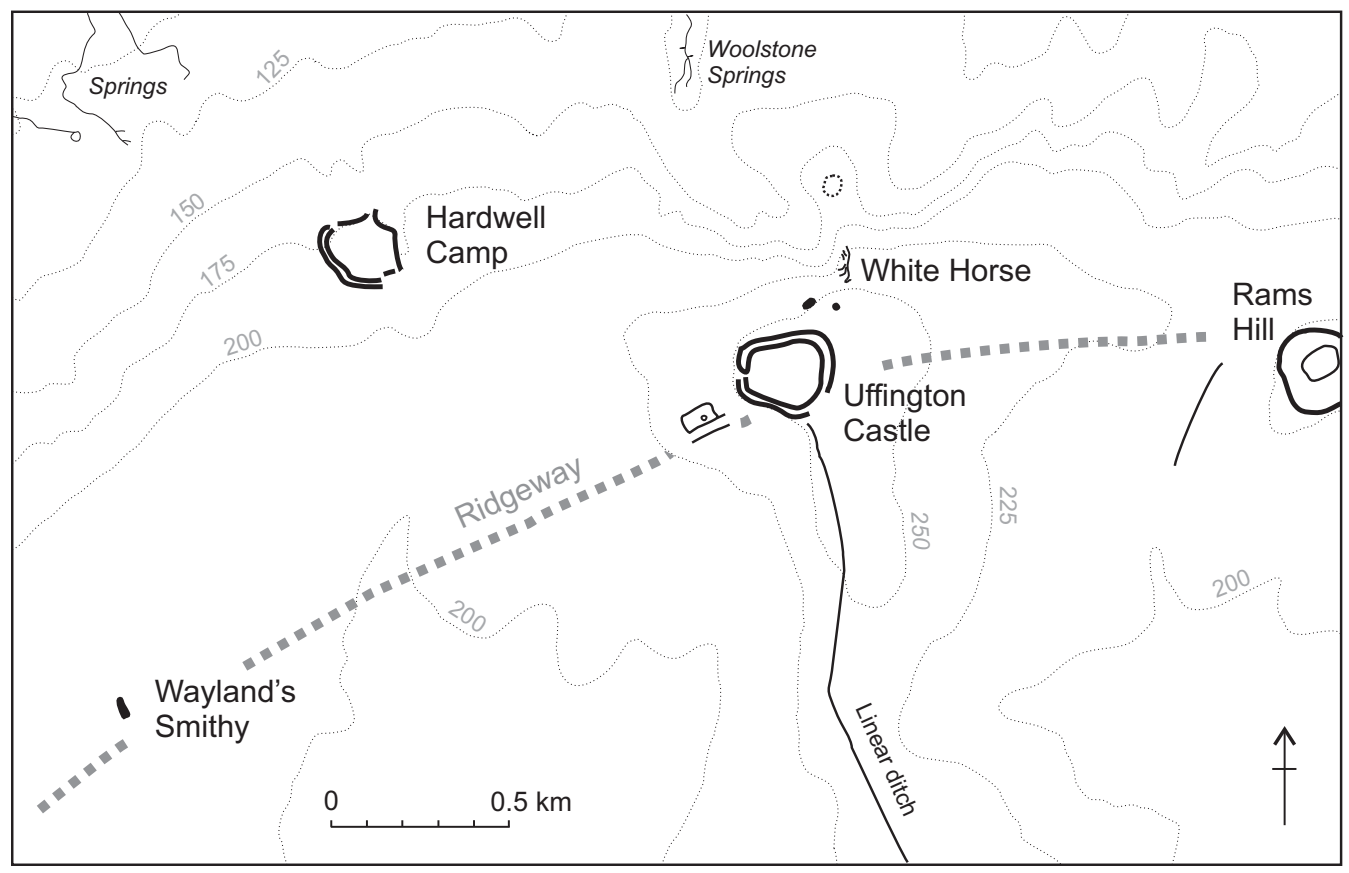

Figure 3. Major monuments within the immediate region.

A key problem with the 'horse as symbol' interpretation is its failure to account for unusual aspects of the geoglyph's location. While its general landscape position is commanding, it is not hugely visible, negating its efficiency as an image to be seen and 'read' along and off the chalk. At this point, the east-west escarpment of the Berkshire Downs pushes north and rises to more than $50 \mathrm{~m}$ above the general scarp level, reaching $261 \mathrm{~m}$ OD. The complex, deep and steep-sided dry valley re-entrant known as the Manger, above which the horse is sited, also makes this a striking landform. Barclay et al. (2003a: 246) note the special configuration of the landscape here: the "juxtaposition of a relatively high hill with a very steep-sided valley below, in an otherwise gently undulating landscape". Seen from the north, the combined effect is visibly to enhance this section of the Downs. From the ridge above the horse, commanding views are offered north across the Vale of the White Horse and the Corallian Ridge to the southern edge of the Cotswold Hills.

Such a location offers the potential for the geoglyph to be highly visible across a wide arc. The positioning of the horse on the north-west-facing slope of the Manger, however, has the effect of blocking views to it from the east (Figure 4). When seen from the north, the views are straight along the back of the horse, from its tail to its head, massively foreshortening the image. The best ground-based perspectives are achieved from Dragon Hill, and from the north-west, close to the springheads at Woolstone Wells, looking down the axis of the Manger (Figure 5). Even from these locations, the position of the horse on a slope of 30$40^{\circ}$ again foreshortens the image. Viewshed analysis shows that there are multiple areas on the same section of ridge that could afford better visibility (Egginton 2011). As it stands, (C) Antiquity Publications Ltd, 2017 


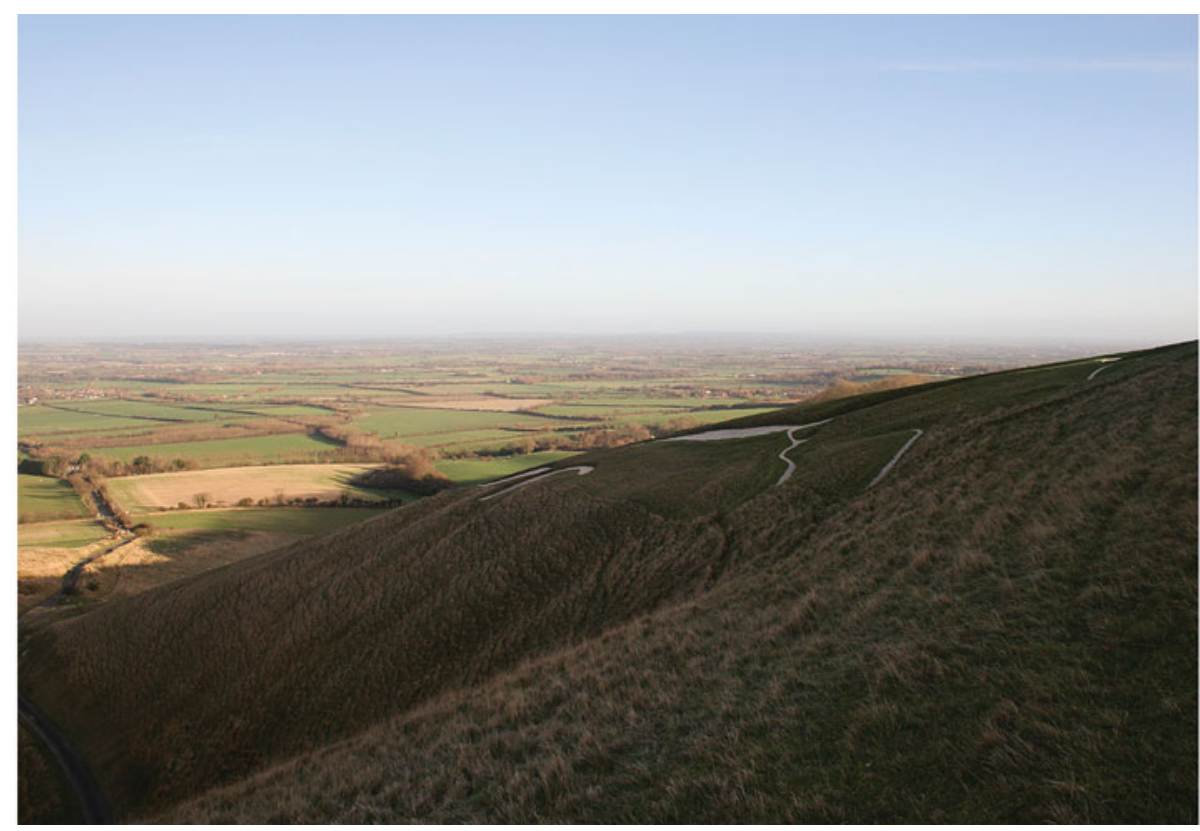

Figure 4. View of the geoglyph looking north and showing its position on the hillslope.

the horse is best seen from the air, a point not lost on early aerial observers (Hauser 2007: 153) (Figure 6).

Two other aspects of the horse's design need to be taken into consideration at this point. The first is that it is laid out so that its body is tilted upwards. The top of the rear of the body is situated at around $235 \mathrm{~m} \mathrm{OD}$, the front at around $240 \mathrm{~m}$ OD, effectively following the angle of the slope of the ridge. This affords it a position that locates the axis of the body parallel to the brow of the ridge when seen from the area of Woolstone Wells. Second, the image adopts a very clear running posture, with head down, tail out and legs in wide gait. Its north-east to south-west alignment, with the head to the south-west, gives the impression of the figure following a broadly east-west route. Taken together, these observations imply that:

- Maximising visibility was not of primary concern in the creation of the horse, and, by implication, its role as a landmark or group symbol must be questioned.

- While not exploiting a position of high visibility, the setting-out of the horse paid careful respect to the details of local topography.

- The design of the horse implies movement.

- When viewed from Dragon Hill and the mouth of the Manger near Woolstone Wells, the horse is afforded the impression of running up along the brow of the ridge, in a westerly direction. If tracked back from the Woolstone Wells vantage, its 'point of origin' would be the flat-topped knoll of Dragon Hill.

A final observation is that the aspect of the figure-moving upwards and to the westfollows the course of the sun in its east-west journey across the sky as viewed in the northern 


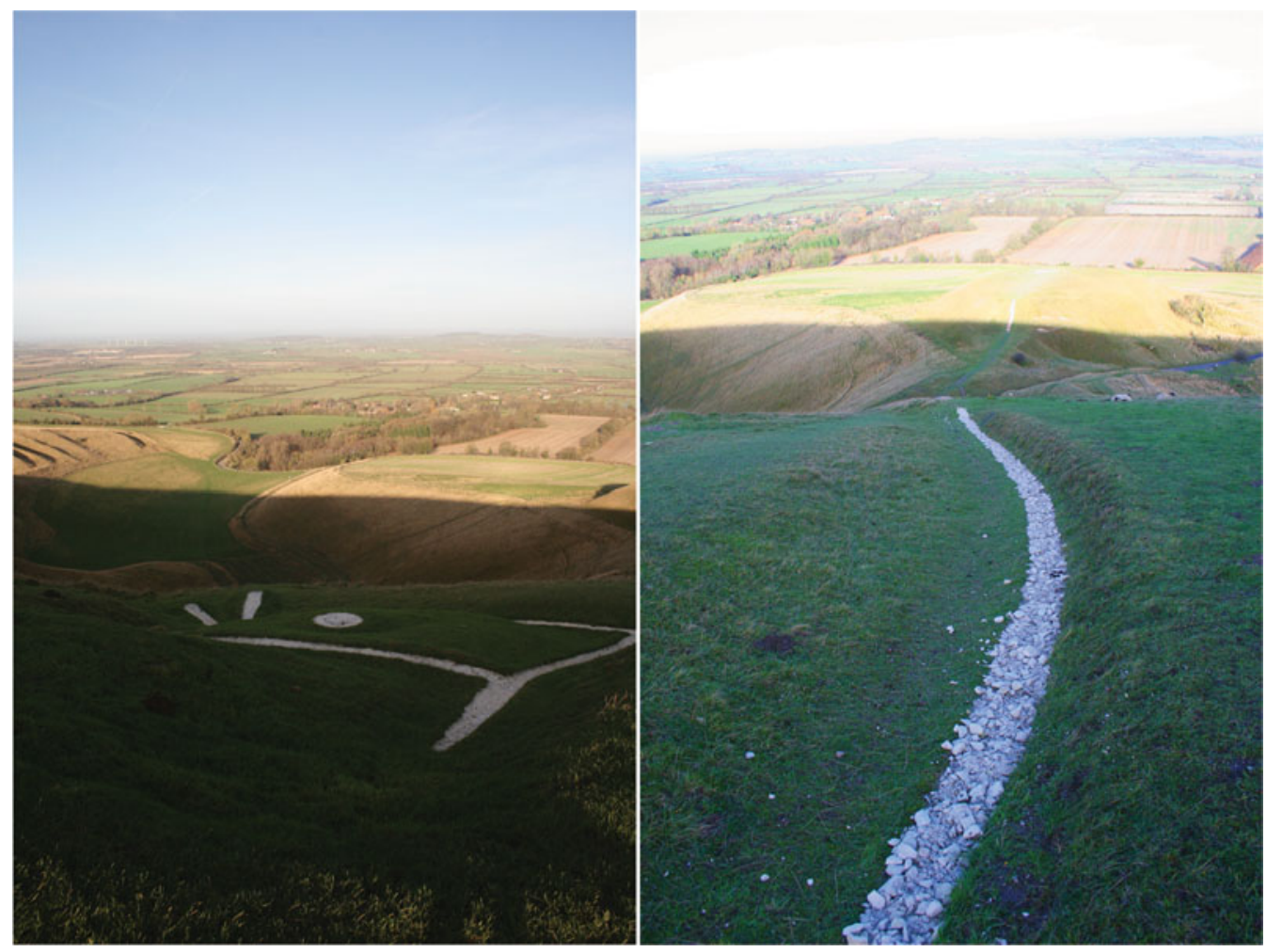

Figure 5. Views from the head and tail of the geoglyph looking towards the Manger, Woolstone Wells (left) and Dragon Hill (right).

hemisphere, and especially during its short passage around midwinter. When observed from Dragon Hill at midwinter, a distinctive effect is created, whereby the sun rises immediately behind the horse and appears to roll just above its body, staying low to the horizon due to the truncation of the lower part of its arc by the high rise of the immediate topography (Figure 7).

\section{The image as sun-horse}

The form and setting of the geoglyph are consistent with it being a sun-horse: an effigy that facilitated the diurnal movement of the sun through the sky. It is therefore better conceived as indexical, in Peircean terms, than as a sign, given that it embodies a causal connection between image and the referenced entity (Peirce 1998). To move interpretation away from its current conceptualisation as a static symbol also allows for conceiving of the geoglyph as periodically animate at the point of conjunction of the image and the moving sun. This position recognises the relational engagement of the image to confluences of time, landscape, cosmic forces and human strategy and history- 'bundling' in Pauketat's terms (2012). Its relationship with other features in the landscape, both topographic and constructed, also becomes an issue, and one that will be explored further later.

(C) Antiquity Publications Ltd, 2017 


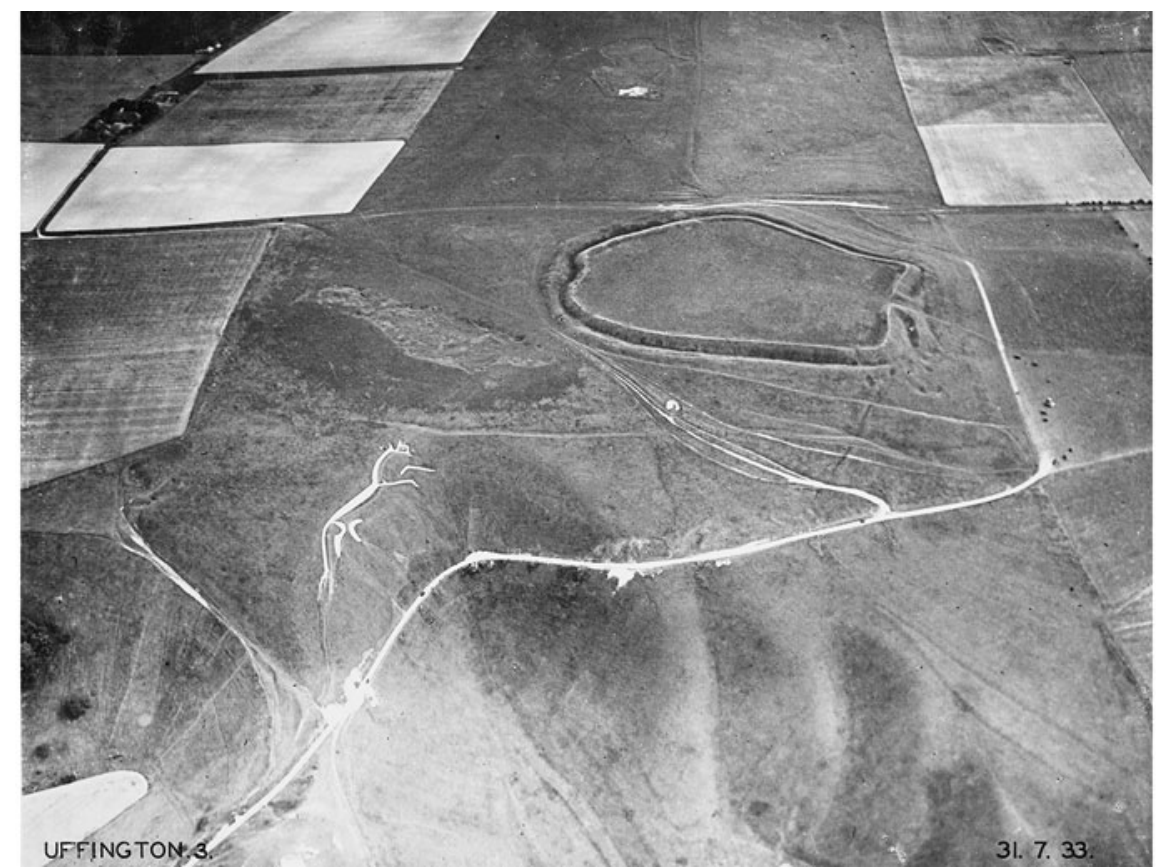

Figure 6. The Uffington geoglyph and Uffington hillfort from the north (Major George Allen Air Archive, image number AA0239 (negative number 1240), 31/07/1933, (c) Ashmolean Museum, University of Oxford).

As a sun-horse, an immediate analogy can be drawn with imagery on Scandinavian metalwork and rock art of the mid second to late first millennia BC (Kaul 1998; Bradley 2006), most notably the iconic Trundholm 'Chariot of the Sun' from north-west Zealand dating to Montelius period 2 (c. 1500-1300 BC; Muller 1903; Kaul 2010) (Figure 8). The notion of the sun as divine, pulled across the sky by a horse or horse-drawn chariot during the day, and transported through the underworld at night by boat or chariot, is a recurrent feature of Indo-European mythologies and cosmologies (Kristiansen \& Larsson 2005; West 2007: 201-209). Similar themes recur within the Old Indian Vedic Rigveda, and in Greek and Baltic mythology, including the role of the divine twin-brothers Aśvins/Ashvins/Ašvieniai, saviour or protector figures that travel with the sun and are identified with white horses (Kristiansen \& Larsson 2005: 297; West 2007: 186-91; Sykes 2014: 82). Based upon linguistic/philological evidence, Sykes (2014: 83-84) has recently suggested that the movement from India-Iran to northern and western Europe of this package of mythology and attendant ritual practices went in tandem with the diffusion of domestic horses, as components of a 'common horse culture'. This would fit well with current dates for the introduction of domesticated horses into northern Europe, which, while still equivocal, probably occurred at some point in the first or second quarter of the second millennium BC (Bendrey et al. 2013). While such cosmological schemes are well represented within the corpus of later Nordic prehistoric imagery, the same is not true within the British Isles, perhaps because of the rarity of representational imagery. Of course, transmission may have occurred through other, perishable, media-textiles and tattoos, for example. 


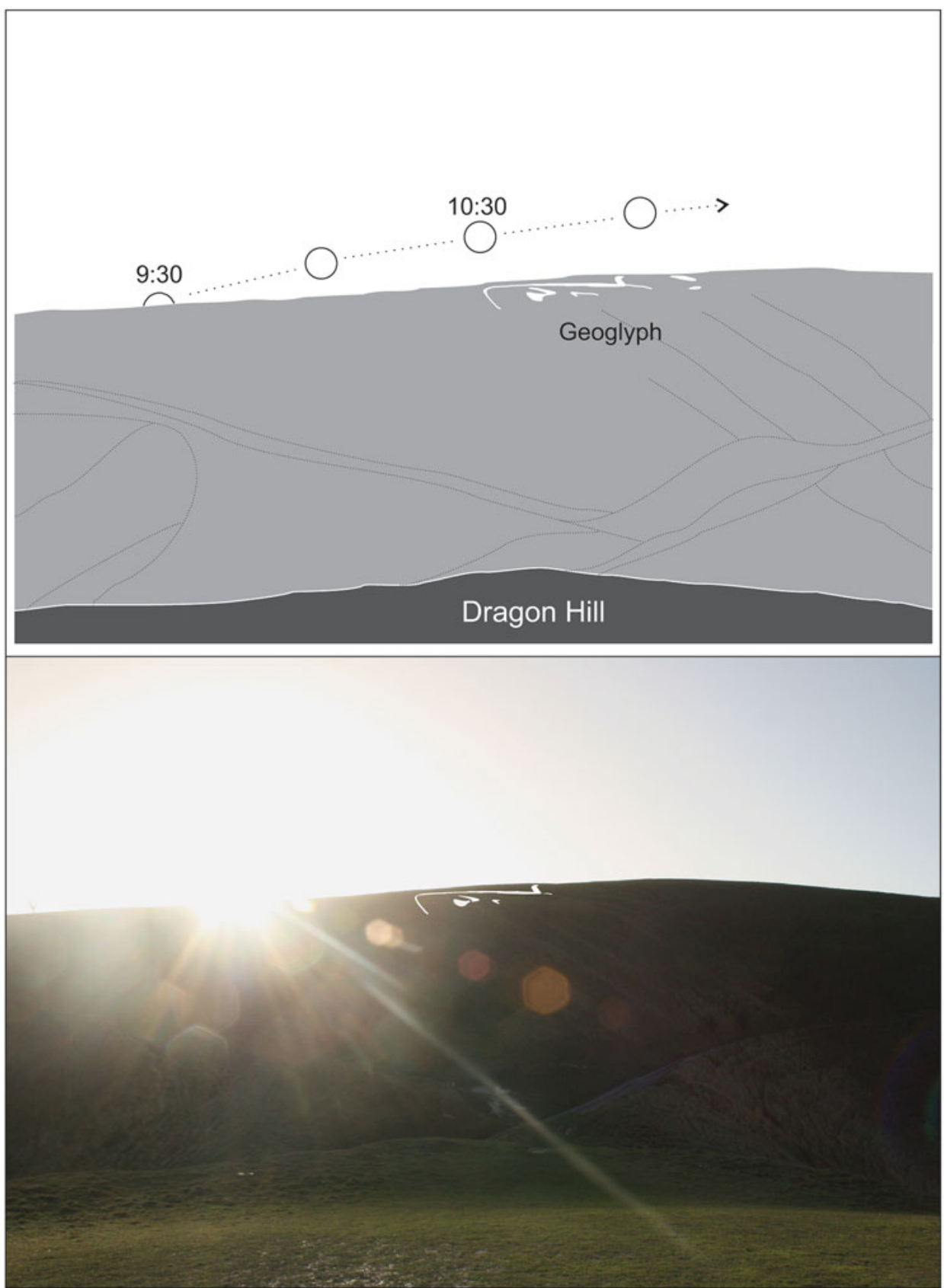

Figure 7. The sun-roll effect as observed from Dragon Hill on 23 December 2015. The geoglyph has been digitally enhanced to afford better visibility.

(C) Antiquity Publications Ltd, 2017 


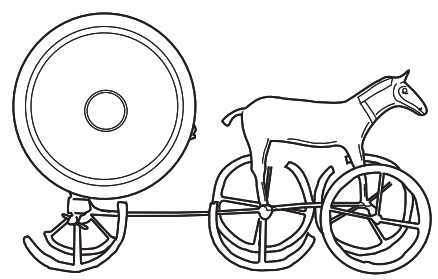

Trundholm chariot

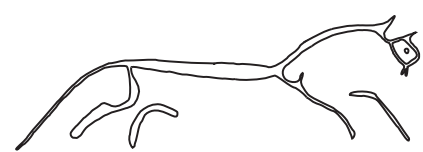

Uffington geoglyph
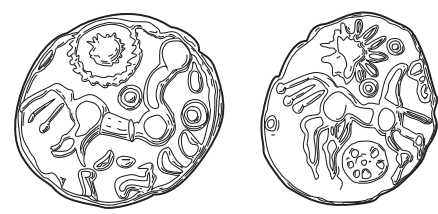

Gold staters (Dobunni, Atrebates)

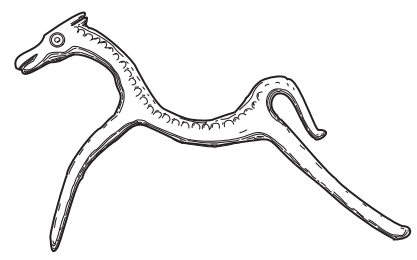

Silchester horse brooch

Neder Hvolris razor

Figure 8. Uffington and related sun-horse and horse imagery from middle-late Bronze Age Denmark (left) and late Iron Age-early Romano-British southern England (right) (not to scale).

\section{The Uffington complex}

The Uffington Horse geoglyph is set apart from the sun-horse imagery found on the portable material culture of the Nordic Bronze Age by its sheer scale-it was created to perform in a landscape. Here, it is argued that it was conceived as the principal element of a complex that drew together natural and artificially created features of pre-existing significance. An archaeologically packed landscape, there is no shortage of significant landmarks at Uffington (Figures $2 \& 3$ ). These can be described as points along the sun's/horse's journey, incorporating portals between the domains of the sky/day and underworld/night. Turning first to natural topographical affordances, one can note the arena-like space created by the re-entrant of the Manger, which offers a striking liminal space between the Vale below and the chalk ridgeway over which the horse traverses. The spring complex at Woolstone Wells affords both the best vantage point for seeing the horse and acts as a place of intersection between surface ('land') and underworld, from which water flows. Located immediately down the ridge-slope from the geoglyph, Dragon Hill could readily be envisaged as another point of emergence — a kind of 'mound of origin' (Figure 9).

The upward and westerly arc of both the horse and the sun takes in other humanmade features that would have been of obvious antiquity and mytho-historic status by the time the geoglyph came into being (Gosden \& Lock 1998). In journey order, these comprise a Bronze Age round barrow followed by a small long mound, both of which are within $150 \mathrm{~m}$ of the horse, and a Bronze Age ring-ditch $550 \mathrm{~m}$ to the south-west. Viewed from Dragon Hill and Woolstone Wells around midwinter, the sun ends its journey in the direction of the chambered Neolithic long barrow of Wayland's Smithy, $2.5 \mathrm{~km}$ to the south-west. Excavation in the 1960s revealed late Bronze Age-early Iron Age disturbance 


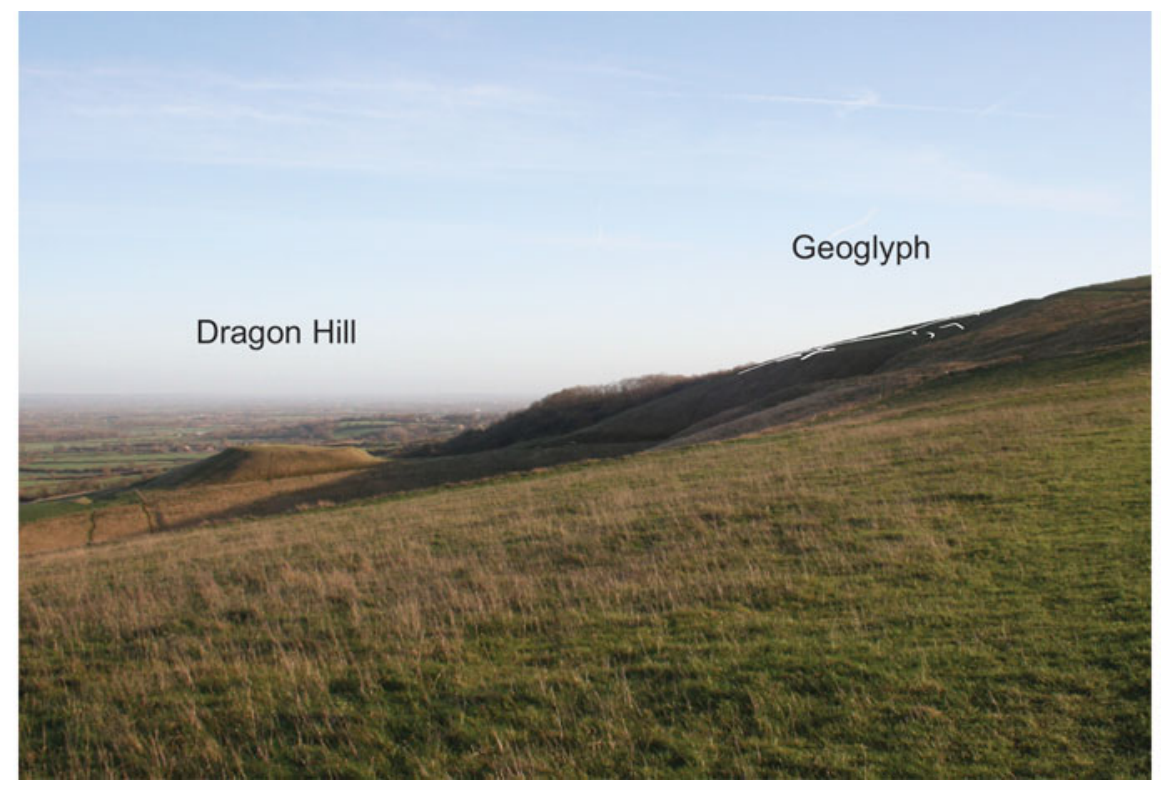

Figure 9. Dragon Hill and the geoglyph from the west. The geoglyph has been digitally enhanced to afford better visibility.

to the mound, pottery and two bronze castings retaining clay cores that make up a horseharness strap-fastening of Ewart Park phase (eighth century BC; Whittle 1991: 87). This is an unusual deposit and indicates an interest in the tomb, potentially within the time frame of the geoglyph's creation. The megalithic component of the second phase of the barrow was visible when the disturbance to the mound and deposition of the castings took place, although by that stage, any sense of the monument's original purpose, or of the agents responsible for its creation, would have been radically reconfigured. It is suggested here that, as an artificial stone 'cave', it was conceived as another portal into the underworld, and the location where the sun-horse began the nocturnal stage of its journey. As its name implies, Anglo-Saxon (and later) folklore links the monument with Wayland, the smith of the gods (Grinsell 1939: 16-20). A connecting thread is also provided by the east-west route of the Ridgeway, potentially serving as a processional route. For this part of its length at least, a pre-Iron Age date can be advanced (Gosden \& Lock 2003).

The imprecision that currently exists in the date of the creation of the geoglyph means that it is difficult to establish connections between the figure and the Uffington Castle, Rams Hill and Hardwell Camp enclosures. At the former two enclosure sites there is episodic, short-duration activity that is hardly consistent with sustained occupation. There are good grounds for arguing that both served as locales for periodic gathering linked to observances at, and maintenance of, the horse (Lock et al. 2003: 124). The first phase of enclosure at Rams Hill dates to between the thirteenth and tenth centuries BC (Needham \& Ambers 1994). It is unusual in several respects, not least the complexity in its periodic circuit redefinition and the presence of multiple entrances. Faunal remains show a notable emphasis on cattle, and particularly high meat-bearing elements (Bradley \& Ellison 1975: 119, 206-15). The limited evidence would best fit a role that involved gathering,

(C) Antiquity Publications Ltd, 2017 
consumption and short-term occupation. Its potential ceremonial role is enhanced by its situation at the head of a valley that leads down to the major early Bronze Age barrow cemetery at Lambourn, 3km to the south-east (Bradley \& Ellison 1975: 219).

The first phase of Uffington Castle came later, in the eighth to sixth centuries BC. Primary activity in the interior was short-lived and left only ephemeral traces. A small amount of fourth-century BC pottery is perhaps linked to reinstatement of the ramparts during this time (Lock et al. 2003: 123). Indeed, Lock et al. (2003: 124) note that "it could have been a sacred place visited, perhaps, seasonally for social activities based on ceremony and ritual". In an inversion of a sequence common among multi-entrance Wessex hillforts, the eastern entrance was blocked during the middle Iron Age, and to the west-a cosmologically circumscribed orientation (Parker Pearson 1996)—was maintained.

\section{Maintaining the horse}

That the Uffington geoglyph remains a visible feature with fidelity to its original form is highly remarkable and entirely due to regular maintenance or 'scouring' (Barclay et al. 2003a: 245). Historical records from the eighteenth and early nineteenth centuries document scouring events at intervals of between 4 and 21 years; and "the conclusion seems inescapable that the horse has been scoured at least once every generation for almost three millennia, if not more" (Schwyzer 1999: 42). Against this repetition of practice-an almost institutionalised process of incorporated memory-work (Connerton 1989) - is the loss at some point in its history of its original role as a sun-horse. Certainly since its first documentary reference in the Abingdon cartularies and appearance on a list of the Wonders of Britain of the later eleventh century AD (Cromarty et al. 2003: 16), it has been the "site of shifting and contested meanings" (Schwyzer 1999: 42).

The post-creation history of the horse prior to the earliest historical record of its existence requires further consideration. Given the longevity of sun-horse mytho-cosmology in the Nordic Bronze and Iron Ages (Kaul 2010: 535), there might be grounds to assume that the sun-horse identification of the Uffington figure was retained over a coeval period, if not for longer. Waddell $(2010,2012)$ has argued that solar boat imagery (i.e. that of the mythic vehicle that took the sun on its nocturnal journey) is a recurrent feature of the decorative schema found on Iron Age and Roman-period La Tène metalwork. Horse imagery on late Iron Age Gallo-Belgic and British gold and silver coinage offers another strand of evidence (Figure 8). Nash Briggs (2009) makes a convincing case for solar horse imagery on first-century BC gold staters, while Creighton has argued that the horse/man iconography common on such coinage enshrined the concept of sacral kingship, the idea that sacred authority was validated through ritualised unions of horse and ruler (Creighton 2000: 22-26). The origins of the latter are to be found within the same Indo-European tradition of the Aśvins/Ashvins/Ašvieniai that delineates the solar horse mythology. Solar and lunar symbols accompany horse designs on a number of Iron Age coin issues from the south and west of England, suggesting that they are also examples of sun-horse imagery.

Evidence for late Iron Age activity at Uffington is largely lacking, although it is present at nearby Rams Hill (Bradley \& Ellison 1975: 69). During the early first millennium AD, activity is more clearly registered and is again indicative of gathering and special practices, 
set within the context of increased agricultural intensification throughout the landscape (Barclay et al. 2003a: 262-63). The long mound to the south-west of the horse became the focus for a major inhumation and cremation cemetery during the fourth century AD, while Anglo-Saxon burials were inserted in the adjacent round barrow (Barclay et al. 2003b: 3847). Sustained late Roman activity within the Uffington hillfort, perhaps overlapping with the use of the long mound cemetery, involved the deposition of large amounts of artefactual material, including many coins (Lock et al. 2003). There is little structural evidence accompanying this, giving the activity something of a 'fair' or 'festival'-like character. The creation of rectangular enclosures adjacent to the earlier Iron Age rampart circuits at both Uffington Castle and Rams Hill during this period may reflect strategies to create more clearly defined sacred spaces. The one on the western side of the Uffington hillfort enclosed an earlier round barrow, again associated with Roman or early Anglo-Saxon burial (Gosden \& Lock 2003). A coin hoard, figurine and burials from the ditch of the enclosure at Rams Hill support interpretation of this as the sacred precinct of a hilltop shrine (Bradley \& Ellison 1975: 71). From the fourth century, the picture is one of periodic gatherings, burials and small-scale votive offerings focused on the ridgetop and the environs of the geoglyph, perhaps with more formalised religious activity contained within specially constructed shrine enclosures. In stark contrast, evidence for Romano-British activity is absent from Segsbury Camp, 9km to the east (Lock et al. 2005). Quite how the horse was understood and engaged with at this time remains uncertain, but it continued to exert a dominant agency.

\section{Conclusion}

The Uffington geoglyph is a truly remarkable monument, but one that has not been easy to accommodate within accounts of later prehistory. It is for this reason that it has become marginalised. Its identification as a sun-horse provides new context, and highlights the potential role of the Uffington complex as a pre-eminent ceremonial focus in later prehistoric Britain. The mytho-cosmological knowledge that was articulated through the creation and maintenance of the geoglyph was by no means unique to this region, possessing a broad-ranging Indo-European currency and perhaps being transmitted via long-distance networks alongside the introduction of domesticated horses (Sykes 2014). It was, however, locally tailored for the region. Key to this translation may have been the physical and historical affordances offered by this section of the Berkshire Downs (Gosden \& Lock 1998). It is a visually dramatic section of chalk escarpment, and one that may probably have already been an important place. The chalk downs are the setting for significant monuments of Neolithic and early Bronze Age date, including Wayland's Smithy and the major round barrow cemetery at Lambourn Seven Barrows to the south. More generally, its location within southern Britain is significant as a node where major topographic entities and routeways intersect. The geoglyph sits on the northern edge of the Wessex chalk, overlooking the Thames Valley and major routes both east and west along it, as well as to the north-west, the Cotswolds and the Severn Valley beyond.

Finally, the regular and repetitive maintenance of the horse over perhaps 3000 or more years-its care-is difficult to match elsewhere in the northern hemisphere and deserves (C) Antiquity Publications Ltd, 2017 
more acknowledgement. That the geoglyph is still with us, occupying a twenty-first-century landscape, is due to more than dumb repetition or un-thought tradition. It has survived because it could be constantly reincorporated within shifting values and religious beliefs, even though the changes in those were often wholesale and dramatic (e.g. the introduction of Christianity and the Reformation).

\section{Acknowledgements}

I would like to thank Richard Bradley, Mhairi Gibson, Mark Gillings, Chris Gosden, Phil MacDonald and Dale Serjeantson, and the two anonymous reviewers, for assistance and constructive comments.

\section{References}

Barclay, A., A.M. Cromarty, C. Gosden, G. Lock, D. Miles, S. Palmer \& M. Robinson. 2003a. The White Horse and its landscape, in D. Miles, S. Palmer, G. Lock, C. Gosden \& A.M. Cromarty, Uffington White Horse and its landscape: investigations at the White Horse Hill Uffington, 1989-95, and Tower Hill Ashbury, 1993-4: 243-68. Oxford: Oxford Archaeology.

Barclay, A., P. Booth, A.M. Cromarty, C. Gosden, D. Miles \& S. Palmer. 2003b. The Manger, Dragon Hill and the barrows, in D. Miles, S. Palmer, G. Lock, C. Gosden \& A.M. Cromarty, Uffington White Horse and its landscape: investigations at the White Horse Hill Uffington, 1989-95, and Tower Hill Ashbury, 1993-4: 29-59. Oxford: Oxford Archaeology.

Bendrey, R., N. Thorpe, A. Outram \& L.H. Van WIJNGAARDEN-BAKKER. 2013. The origins of domestic horses in north-west Europe: new direct dates on the horses of Newgrange, Ireland. Proceedings of the Prehistoric Society 79: 91-103. https://doi.org/10.1017/ppr.2013.3

Bowden, M., S. Ford \& V. Gaffney. 1993. The excavation of a Late Bronze Age artefact scatter on Weathercock Hill. Berkshire Archaeological Journal 74: 69-83.

BRADLEY, R. 1997. Rock art and the prehistory of Europe: signing the land. London: Routledge.

- 2006. Danish razors and Swedish rocks: cosmology and the Bronze Age landscape. Antiquity 80: 372-89. https://doi.org/10.1017/S0003598X00093698

Bradley, R. \& A. Ellison. 1975. Rams Hill: a Bronze Age defended enclosure and its landscape (British Archaeological Reports British series 19). Oxford: British Archaeological Reports.

Connerton, P. 1989. How societies remember. Cambridge: Cambridge University Press. https://doi.org/10.1017/CBO9780511628061

Crawford, O.G.S. 1929. The Giant of Cerne and other hill-figures. Antiquity 3: 277-82. https://doi.org/10.1017/S0003598X0000346X
Creighton, J. 2000. Coins and power in Late Iron Age Britain. Cambridge: Cambridge University Press. https://doi.org/10.1017/CBO9780511489587

Cromarty, A.M., D. Miles, S. Palmer \& R. Bailey. 2003. Documentary evidence, work of antiquaries and previous investigations, in D. Miles, S. Palmer, G. Lock, C. Gosden \& A.M. Cromarty, Uffington White Horse and its landscape: investigations at the White Horse Hill Uffington, 1989-95, and Tower Hill Ashbury, 1993-4: 15-27. Oxford: Oxford Archaeology.

Egginton, A. 2011. The landscape context of chalk geoglyphs in southern England. Unpublished MSc dissertation, University of Southampton.

Gosden, C. \& G. Lock. 1998. Prehistoric histories. World Archaeology 30: 2-12. https://doi.org/10.1080/00438243.1998.9980393

- 2003. The linear ditch, the Ridgeway and the enclosure, in D. Miles, S. Palmer, G. Lock, C. Gosden \& A.M. Cromarty, Uffington White Horse and its landscape: investigations at the White Horse Hill Uffington, 1989-95, and Tower Hill Ashbury, 1993-4: 127-35. Oxford: Oxford Archaeology.

- 2013. Histories in the making: excavations at Alfred's Castle, 1998-2000. Oxford: Oxford University School of Archaeology.

Grinsell, L.V. 1939. White Horse Hill and surrounding country. London: Saint Catherine.

Hauser, K. 2007. Shadow sites: photography, archaeology and the British landscape 1927-1955. Oxford: Oxford University Press.

Hughes, T. 1859. The scouring of the White Horse. Cambridge: Macmillan.

Jones, A. 2012. Prehistoric materialities: becoming material in prehistoric Britain and Ireland. Oxford: Oxford University Press. https://doi.org/10.1093/acprof: osobl/9780199556427.001.0001

Kaul, F. 1998. Ships on bronzes: a study in Bronze Age religion and iconography. Copenhagen: National Museum. 


\section{Joshua Pollard}

- 2010. The sun image from Trundholm ('The Chariot of the Sun') - a commented history of research, in H. Meller \& F. Bertemes (ed.) Der Griff nach den Sternen: Wie Europas Eliten zu Macht und Reichtum kamen: 521-36. Halle (Saale): Landesamt für Denkmalpflege und Archäologie Sachsen-Anhalt/Landesmuseum für Vorgeschichte.

Kristiansen, K. \& T.B. Larsson. 2005. The rise of Bronze Age society: travels, transmissions and transformations. Cambridge: Cambridge University Press.

Lock, G., D. Miles, S. Palmer \& A.M. Cromarty. 2003. The hillfort, in D. Miles, S. Palmer, G. Lock, C. Gosden \& A.M. Cromarty, Uffington White Horse and its landscape: investigations at the White Horse Hill Uffington, 1989-95, and Tower Hill Ashbury, 1993-4: 79-126. Oxford: Oxford Archaeology.

Lock, G., C. Gosden \& P. Daley. 2005. Segsbury Camp: excavations in 1996 and 1997 at an Iron Age hillfort on the Oxfordshire Ridgeway. Oxford: Oxford University School of Archaeology.

LucAs, G. 2005. The archaeology of time. London: Routledge.

MARPLes, M. 1949. White horses and other hill figures. London: Country Life.

Miles, D., S. Palmer \& A.M. Cromarty. 2003a. The White Horse, in D. Miles, S. Palmer, G. Lock, C. Gosden \& A.M. Cromarty, Uffington White Horse and its landscape: investigations at the White Horse Hill Uffington, 1989-95, and Tower Hill Ashbury, 1993-4: 61-78. Oxford: Oxford Archaeology.

Miles, D., G. Campbell \& A.M. Cromarty. 2003 b. Tower Hill, Ashbury, in D. Miles, S. Palmer, G. Lock, C. Gosden \& A.M. Cromarty, Uffington White Horse and its landscape: investigations at the White Horse Hill Uffington, 1989-95, and Tower Hill Ashbury, 1993-4: 137-58. Oxford: Oxford Archaeology.

Muller, S. 1903. Sollbilidet frå Trundholm. København: Nordiske Fortidsimnder.

NASH BRIgGS, D. 2009. Reading the images on Iron Age coins: 2. Horses of the day and night. Chris Rudd List 106: 2-4. Available at: http://www.celticcoins.com/wp-content/uploads/ 2014/12/The-sun-horse.pdf (accessed 6 December 2016).
Needham, S. \& J. Ambers. 1994. Redating Rams Hill and reconsidering Bronze Age enclosure. Proceedings of the Prehistoric Society 60: 225-43. https://doi.org/10.1017/S0079497X00003443

Parker Pearson, M. 1996. Food, fertility and front doors in the first millennium BC, in T.C. Champion \& J. Collis (ed.) The Iron Age in Britain and Ireland: recent trends: 117-32. Sheffield: J.R. Collis.

Pauketat, T. 2012. An archaeology of the cosmos. Abingdon: Routledge.

PeIrce, C.S. 1998. The essential Peirce: selected philosophical writings. Bloomington: Indiana University Press.

Piggott, S. 1931. The Uffington White Horse. Antiquity 5: 37-46. https://doi.org/10.1017/S0003598X00005585

Rees-Jones, J. \& M. Tite. 2003. Optically stimulated luminescence (OSL) dating results from the White Horse and linear ditch, in D. Miles, S. Palmer, G. Lock, C. Gosden \& A.M. Cromarty, Uffington White Horse and its landscape: investigations at the White Horse Hill Uffington, 1989-95, and Tower Hill Ashbury, 1993-4: 269-71. Oxford: Oxford Archaeology.

Schwyzer, P. 1999. The scouring of the White Horse: archaeology, identity, and 'heritage'. Representations 65: 42-62. https://doi.org/10.1525/rep.1999.65.1.01p0032n

Sykes, N. 2014. Beastly questions: animal answers to archaeological issues. London: Bloomsbury.

WAdDell, J. 2010. The elusive image, in G. Cooney, K. Becker, J. Coles, M. Ryan \& S. Sievers (ed.) Relics of old decency: archaeological studies in later prehistory: 339-47. Dublin: Wordwell.

- 2012. Tal-y-Llyn and the nocturnal voyage of the sun, in W.J. Britnell \& R.J. Silvester (ed.) Reflections on the past: essays in honour of Frances Lynch: 337-50. Welshpool: Cambrian Archaeological Association.

WeSt, M.L. 2007. Indo-European poetry and myth. Oxford: Oxford University Press. https://doi.org/10.1093/acprof: oso/9780199280759.001.0001

Whittle, A. 1991. Wayland's Smithy, Oxfordshire: excavations at the Neolithic tomb in 1962-63 by R.J.C. Atkinson and S. Piggott. Proceedings of the Prehistoric Society 57: 61-101. https://doi.org/10.1017/S0079497X00004515

Received: 1 February 2016; Accepted: 6 May 2016; Revised: 12 May 2016

(C) Antiquity Publications Ltd, 2017 